\title{
Data analysis for electrolyte systems : a method illustrated on alkali halides in water
}

\author{
Santiago Vaque Aura1; Juan-Sebastian Roa Pinto1; Nicolas Ferrandoㄹ; Jean-Charles de \\ Hemptinne ${ }^{1 *}$; Antoon ten Kate ${ }^{2}$; Susanna Kuitunen ${ }^{3}$; Nikolaos Diamantonis ${ }^{4}$; Thomas \\ Gerlach $^{5}$; Manfred Heilig ${ }^{6}$; Gaetan Becker ${ }^{7}$; Mathias Brehelin ${ }^{8}$
}

1: IFP Energies nouvelles, 1 et 4, avenue de Bois-Préau, 92852 Rueil-Malmaison Cedex - France 2: Nouryon Zutphenseweg 107418 AJ Deventer, The Netherlands

3 : Neste Engineering Solutions Oy; PO Box 310; FI-06101 Porvoo, Finland

4: Applied Sciences, BP International Itd., Sunbury-on-Thames, TW16 7LN, UK

5: Bayer AG, Process Technologies, Building E41, 51368 Leverkusen, Germany

6: BASF SE, Chemical Process Modeling, Carl-Bosch-Strasse 38, 67056 Ludwigshafen am Rhein, Germany

7: ORANO Projets - 1 rue des Hérons - 78182 Montigny Le Bretonneux - France

8: Solvay RICL, 85 avenue des Frères Perret BP62 69192 Saint-Fons, France

*: corresponding author: j-charles.de-hemptinne@ifpen.fr 


\section{Appendix : References for the codes used}

Activity Coefficient Data

\begin{tabular}{|l|l|}
\hline DDB-ELE:2008-JAN/1100 & {$[1]$} \\
\hline DDB-ELE:2008-JAN/1878 & {$[2]$} \\
\hline DDB-ELE:2008-JAN/207 & {$[3]$} \\
\hline DDB-ELE:2008-JAN/2451 & {$[4]$} \\
\hline DDB-ELE:2008-JAN/2607 & {$[5]$} \\
\hline DDB-ELE:2008-JAN/3794 & {$[6]$} \\
\hline DDB-ELE:2008-JAN/3852 & {$[7]$} \\
\hline DDB-ELE:2008-JAN/3959 & {$[8]$} \\
\hline DDB-ELE:2008-JAN/4408 & {$[9]$} \\
\hline DDB-ELE:2008-JAN/5043 & {$[10]$} \\
\hline DDB-ELE:2008-JAN/5062 & {$[11]$} \\
\hline DDB-ELE:2008-JAN/5795 & {$[12]$} \\
\hline DDB-ELE:2008-JAN/5816 & {$[13]$} \\
\hline DDB-ELE:2008-JAN/5890 & {$[14]$} \\
\hline DDB-ELE:2009-AUG/5781 & {$[15]$} \\
\hline DDB-ELE:2009-AUG/7482 & {$[16]$} \\
\hline DDB-ELE:2009-JAN/6432 & {$[17]$} \\
\hline DDB-ELE:2009-JAN/6576 & {$[18]$} \\
\hline DDB-ELE:2010-DEC/7619 & {$[19]$} \\
\hline
\end{tabular}

\begin{tabular}{|l|l|}
\hline DDB-ELE:2011-DEC/5020 & {$[20]$} \\
\hline DDB-ELE:2011-DEC/5026 & {$[21]$} \\
\hline DDB-ELE:2011-DEC/8169 & {$[22]$} \\
\hline DDB-ELE:2011-DEC/8229 & {$[23]$} \\
\hline DDB-ELE:2011-DEC/8240 & {$[24]$} \\
\hline DDB-ELE:2012-NOV/1979 & {$[25]$} \\
\hline DDB-ELE:2012-NOV/8727 & {$[26]$} \\
\hline DDB-ELE:2013-DEC/9070 & {$[27]$} \\
\hline DDB-ELE:2015/10163 & {$[28]$} \\
\hline DDB-ELE:2015/10200 & {$[29]$} \\
\hline DDB-ELE:2015-Mar/9879 & {$[30]$} \\
\hline DDB-ELE:2015-Mar/9947 & {$[31]$} \\
\hline DDB-ELE:2016/11122 & {$[32]$} \\
\hline DDB-ELE:2016/11406 & {$[33]$} \\
\hline DDB-ELE:2016/11706 & {$[34]$} \\
\hline DDB-ELE:2017/12340 & {$[35]$} \\
\hline DDB-ELE:2017/12725 & {$[36]$} \\
\hline DDB-ELE:2017/13228 & {$[37]$} \\
\hline DDB-ELE:2017/13341 & {$[38]$} \\
\hline
\end{tabular}

Osmotic Coefficient Data

\begin{tabular}{|l|l|}
\hline DDB-ELE:2008-JAN/1045 & {$[1]$} \\
\hline DDB-ELE:2008-JAN/1911 & {$[39]$} \\
\hline DDB-ELE:2008-JAN/206 & {$[3]$} \\
\hline DDB-ELE:2008-JAN/2519 & {$[40]$} \\
\hline DDB-ELE:2008-JAN/2815 & {$[41]$} \\
\hline DDB-ELE:2008-JAN/2873 & {$[35]$} \\
\hline DDB-ELE:2008-JAN/3401 & {$[42]$} \\
\hline DDB-ELE:2008-JAN/4502 & {$[43]$} \\
\hline DDB-ELE:2008-JAN/4507 & {$[44]$} \\
\hline DDB-ELE:2008-JAN/4979 & {$[45]$} \\
\hline DDB-ELE:2008-JAN/5047 & {$[10]$} \\
\hline DDB-ELE:2008-JAN/57 & {$[46]$} \\
\hline DDB-ELE:2008-JAN/5780 & {$[15]$} \\
\hline DDB-ELE:2008-JAN/6100 & {$[47]$} \\
\hline DDB-ELE:2008-JAN/6146 & {$[48]$} \\
\hline DDB-ELE:2009-JAN/6358 & {$[49]$} \\
\hline DDB-ELE:2011-DEC/4119 & {$[50]$} \\
\hline DDB-ELE:2012-NOV/8521 & {$[51]$} \\
\hline
\end{tabular}

\begin{tabular}{|l|l|}
\hline DDB-ELE:2012-NOV/8794 & {$[52]$} \\
\hline DDB-ELE:2013-DEC/9069 & {$[27]$} \\
\hline DDB-ELE:2015/10050 & {$[53]$} \\
\hline DDB-ELE:2015/10062 & {$[54]$} \\
\hline DDB-ELE:2015/10085 & {$[55]$} \\
\hline DDB-ELE:2015/10469 & {$[56]$} \\
\hline DDB-ELE:2015/10752 & {$[57]$} \\
\hline DDB-ELE:2015/2097 & {$[58]$} \\
\hline DDB-ELE:2015-Mar/9762 & {$[59]$} \\
\hline DDB-ELE:2016/10876 & {$[60]$} \\
\hline DDB-ELE:2016/10908 & {$[61]$} \\
\hline DDB-ELE:2016/11277 & {$[62]$} \\
\hline DDB-ELE:2017/12042 & \\
\hline DDB-ELE:2017/12057 & {$[63]$} \\
\hline DDB-ELE:2017/12064 & {$[64]$} \\
\hline DDB-ELE:2017/12679 & {$[65]$} \\
\hline DDB-ELE:2017/12979 & {$[66]$} \\
\hline
\end{tabular}

Bubble Pressure Data 


\begin{tabular}{|l|l|}
\hline 2008-FEB-20-14:50/40751 & {$[67]$} \\
\hline DDB-ELE:2008-JAN/1190 & {$[68]$} \\
\hline DDB-ELE:2008-JAN/124 & {$[69]$} \\
\hline DDB-ELE:2008-JAN/1261 & {$[70]$} \\
\hline DDB-ELE:2008-JAN/2053 & {$[71]$} \\
\hline DDB-ELE:2008-JAN/2537 & {$[72]$} \\
\hline DDB-ELE:2008-JAN/324 & {$[73]$} \\
\hline DDB-ELE:2008-JAN/3795 & {$[6]$} \\
\hline DDB-ELE:2008-JAN/4204 & {$[74]$} \\
\hline DDB-ELE:2008-JAN/428 & {$[75]$} \\
\hline DDB-ELE:2008-JAN/4560 & {$[76]$} \\
\hline DDB-ELE:2008-JAN/518 & {$[77]$} \\
\hline DDB-ELE:2008-JAN/557 & {$[78]$} \\
\hline DDB-ELE:2008-JAN/6267 & {$[79]$} \\
\hline
\end{tabular}

\begin{tabular}{|l|l|}
\hline DDB-ELE:2009-AUG/7027 & {$[80]$} \\
\hline DDB-ELE:2010-DEC/7547 & {$[81]$} \\
\hline DDB-ELE:2012-NOV/8577 & {$[82]$} \\
\hline DDB-ELE:2013-DEC/8986 & {$[83]$} \\
\hline DDB-ELE:2015/10157 & {$[84]$} \\
\hline DDB-ELE:2015/10160 & {$[85]$} \\
\hline DDB-ELE:2015/10238 & {$[86]$} \\
\hline DDB-ELE:2015-Mar/9888 & {$[87]$} \\
\hline DDB-ELE:2016/11101 & {$[88]$} \\
\hline DDB-ELE:2016/11567 & {$[89]$} \\
\hline DDB-VLE:2007-NOV/25858 & {$[90]$} \\
\hline 2008-FEB-20-14:50/42462 & {$[91]$} \\
\hline 2008-FEB-20-14:50/40880 & {$[75]$} \\
\hline
\end{tabular}

Enthalpy of Solution Data

\begin{tabular}{|l|l|}
\hline 2008-FEB-20-14:50/16488 & {$[92]$} \\
\hline $2008-F E B-20-14: 50 / 16003$ & {$[93]$} \\
\hline $2008-F E B-20-14: 50 / 15876$ & {$[94]$} \\
\hline $2008-F E B-20-14: 50 / 15297$ & {$[95]$} \\
\hline $2008-F E B-20-14: 50 / 15283$ & {$[96]$} \\
\hline $2008-F E B-20-14: 50 / 16276$ & {$[97]$} \\
\hline $2008-F E B-20-14: 50 / 16126$ & {$[98]$} \\
\hline $2008-F E B-20-14: 50 / 15896$ & {$[99]$} \\
\hline
\end{tabular}

\begin{tabular}{|l|l|}
\hline 2008-FEB-20-14:50/15657 & {$[100]$} \\
\hline 2008-FEB-20-14:50/15392 & {$[101]$} \\
\hline 2008-FEB-20-14:50/15079 & {$[102]$} \\
\hline $2008-F E B-20-14: 50 / 15067$ & {$[103]$} \\
\hline $2008-F E B-20-14: 50 / 14934$ & {$[104]$} \\
\hline $2008-F E B-20-14: 50 / 14482$ & {$[105]$} \\
\hline $2008-F E B-20-14: 50 / 13357$ & {$[106]$} \\
\hline $2008-F E B-20-14: 50 / 13394$ & {$[107]$} \\
\hline
\end{tabular}

\section{Bibliographie}

[1] Robinson R.A., Stokes R.H. Tables of osmotic and activity coefficients of electrolytes in aqueous solution at 25[degree] C, Transactions of the Faraday Society, 1949, 45, 0, 612-624. DOI: 10.1039/TF9494500612.

[2] Yan W.D. Study on Thermodynamic Properties of Electrolyte Solutions, 1993.

[3] Hamer W.J., Wu Y.C. Osmotic Coefficients and Mean Activity Coefficients of Uni-Univalent Electrolytes in Water at 25 C, Journal of Physical and Chemical Reference Data, 1972, 1, 4, 10471099.

[4] Rabie H., Wilczek-Vera G., Vera J. Activities of Individual Ions From Infinite Dilution to Saturated Solutions : Journal of Solution Chemistry, Journal of Solution Chemistry, 1999, 28, 7, 885-913.

[5] Malahias L., Popovych O. Activity coefficients and transfer free energies of potassium chloride in methanol-water solvents at 25.degree.C, J. Chem. Eng. Data, 1982, 27, 2, 105-109. DOI: 10.1021/je00028a001.

[6] Pearce J.N., Nelson A.F. The vapor pressures of aqueous solutions of lithium nitrate and the activity coefficients of some alkali salts in solutions of high concentration at $25^{\circ} \mathrm{C}$ : Journal of the American Chemical Society, Journal of the American Chemical Society, 1932, 54, 9, 3544-3555. DOI: $10.1021 / \mathrm{ja01348a008.}$ 
[7] Zhang J., Gao S., Xia S. Thermodynamic Study on Mixed Electrolyte $\mathrm{KCl}$ and $\mathrm{K} 2 \mathrm{SO} 4$ Aqueous Systems from EMF Measurements at 298.15 K, J. Chem. Eng. Data, 2004, 49, 3, 444-448. DOI: 10.1021/je030182n.

[8] Schneider A.C., Pasel C., Luckas M., Schmidt K.G., Herbell J.D. Bestimmung von Ionenaktivitatskoeffizienten in wassrigen Losungen mit Hilfe ionenselektiver Elektroden, Chemie Ingenieur Technik, 2003, 75, 3, 244-249.

[9] Mendonça A.J. de, Juusola P.M. Activity coefficients of dipotassium phthalate and potassium hydrogen phthalate in water at 298.15K, Fluid Phase Equilibria, 2005, 231, 1, 114-124. DOI: 10.1016/j.fluid.2005.01.006.

[10] Hornibrook W.J., Janz G.J., Gordon A.R. The Thermodynamics of Aqueous Solutions of Potassium Chloride at Temperatures from $15-45^{\circ}$ from E. m. f. Measurements on Cells with Transference, J. Am. Chem. Soc., 1942, 64, 3, 513-516. DOI: 10.1021/ja01255a011.

[11] Shedlovsky T., MacInnes D.A. The Determination of Activity Coefficients from the Potentials of Concentration Cells with Transference. III. Potassium Chloride. IV. Calcium Chloride, J. Am. Chem. Soc., 1937, 59, 3, 503-506. DOI: 10.1021/ja01282a023.

[12] Wilczek-Vera G., Rodil E., Vera J.H. Towards accurate values of individual ion activities: Additional data for $\mathrm{NaCl}, \mathrm{NaBr}$ and $\mathrm{KCl}$, and new data for $\mathrm{NH} 4 \mathrm{Cl}:$ A Festschrift in Honor of John M. Prausnitz, Fluid Phase Equilibria, 2006, 241, 10̂çô2, 59-69.

[13] Akerloef G. Activity coefficients of sodium, potassium and lithium chlorides and hydrochloric acid at infinite dilution in water-methyl alcohol mixtures : Journal of the American Chemical Society, Journal of the American Chemical Society, 1930, 52, 6, 2353-2368. DOI: 10.1021/ja01369a023.

[14] Robinson R.A., Sinclair D.A. The Activity Coefficients of the Alkali Chlorides and of Lithium lodide in Aqueous Solution from Vapor Pressure Measurements : Journal of the American Chemical Society, Journal of the American Chemical Society, 1934, 56, 9, 1830-1835. DOI: 10.1021/ja01324a003.

[15] Stokes R.H., Levien B.J. The Osmotic and Activity Coefficients of Zinc Nitrate, Zinc Perchlorate and Magnesium Perchlorate. Transference Numbers in Zinc Perchlorate Solutions : Journal of the American Chemical Society, Journal of the American Chemical Society, 1946, 68, 2, 333-337. DOI: 10.1021/ja01206a055.

[16] Lietzke M.H., Stoughton R. The Activity Coefficient of Potassium Chloride in Aqueous Solution as measured with a Cation-Sensitive Glass Electrode, J. Tenn. Acad. Sci., 1967, 42, $26-27$.

[17] Caramazza R. Measurement of the activity coefficients of potassium chloride in aqueous solution, Gazz. Chim. It., 1960, 90, 1721-1729.

[18] Smith R.P. The Activity Coefficient of Potassium Chloride in Aqueous Solutions at $0^{\circ}$ from Electromotive Force and Freezing Point Data, J. Am. Chem. Soc., 1933, 55, 8, 3279-3282. DOI: 10.1021/ja01335a038.

[19] Lebed V.I., Aleksandrov V.V. Electromotive Forces and Normal Potentials of Cells without Transport at Various Temperatures, Russ.J.Phys.Chem., 1964, 38, 11, 1414-1417.

[20] Harned H.S., Cook M.A. The Thermodynamics of Aqueous Potassium Chloride Solutions from Electromotive Force Measurements, J. Am. Chem. Soc., 1937, 59, 7, 1290-1292. DOI: 10.1021/ja01286a038.

[21] Harned H.S., Cook M.A. The Activity and Osmotic Coefficients of Some Hydroxide-Chloride Mixtures in Aqueous Solution, J. Am. Chem. Soc., 1937, 59, 10, 1890-1893. DOI: 10.1021/ja01289a028. 
[22] Harned H.S. THE ELECTROMOTIVE FORCES OF UNI-UNIVALENT HALIDES IN CONCENTRATED AQUEOUS SOLUTIONS, J. Am. Chem. Soc., 1929, 51, 2, 416-427. DOI: 10.1021/ja01377a011.

[23] Hernandez-Luis F., Rodriguez-Raposo R., Galleguillos H.R., Morales J.W. Activity Coefficients of $\mathrm{NaCl}$ in Aqueous Mixtures with High Relative Permittivity Cosolvent: Ethylene Carbonate + Water at $298.15 \mathrm{~K}$ : Journal of Chemical \& Engineering Data, Journal of Chemical \& Engineering Data, 2010, 55, 9, 3349-3355. DOI: 10.1021/je100121u.

[24] Ma Y., Li S., Zhai Q., Jiang Y., Hu M. Activity Coefficients of Potassium Chloride in Ethylene Glycol-Water Mixtures Using Electromotive Force Measurements at (278.15, 288.15, 298.15, and 308.15) K, J. Chem. Eng. Data, 2010, 55, 4, 1573-1579. DOI: 10.1021/je900690d.

[25] Kiepe J., Topphoff M. Unpublished data, 1999, Brevet.

[26] Ghalami-Choobar B., Mohammadian M. Thermodynamic modeling of the $\mathrm{KCl}+\mathrm{glucose}+$ water system based on potentiometric measurements at 298.15K, Journal of Molecular Liquids, 2010, 154, 1, 26-30. DOI: 10.1016/j.molliq.2010.03.008.

[27] Robinson R.A. The Vapor Pressures of Solutions of Potassium Chloride and Sodium Chloride, Trans. R. Soc. N.Z., 1946, 75, 2, 203-217.

[28] Robinson R.A. The Activity Coefficients of some Alkali Halides at $25^{\circ} \mathrm{C}$, Trans. Faraday Soc., 1939, 35, 1217-1220.

[29] Getman F.H. THE ACTIVITIES OF THE IONS IN AQUEOUS SOLUTIONS OF SOME "STRONG" ELECTROLYTES, J. Am. Chem. Soc., 1920, 42, 8, 1556-1564. DOI: 10.1021/ja01453a005.

[30] Yan W., Liu W., Han S. Measurement of Components Activity Coefficients of Mixed Electrolyte by EMF Method, Gaoxiao Huaxue Gongcheng Xuebao, 1994, 8, 33-39.

[31] Ghalami-Choobar B., Shekofteh-Gohari M., Sayyadi-Nodehi F. Thermodynamic study of ternary electrolyte $\mathrm{KCl}+1-\mathrm{PrOH}+$ water system based on Pitzer and Pitzer - Simonson - Clegg models using potentiometric measurements, Journal of Molecular Liquids, 2013, 188, 49-54. DOI: 10.1016/j.molliq.2013.09.011.

[32] Chistyakov Y., Safonova L.P., Egorova I. Aktivitätskoeffizienten von Kaliumchlorid in wässrigen Alkohol (C3H8On)-Lösungen, Izv. Vyssh. Uchebn. Zaved. Khim. Khim. Tekhnol., 1980, 23, 717722.

[33] Khoshkbarchi M.K., Vera J.H. Measurement and modeling of activities of amino acids in aqueous salt systems, AlChE Journal, 1996, 42, 8, 2354-2364.

[34] Sang S.-H., Zhou M.-F., Zhong S.-Y., Zhang J.-J. Mean Activity Coefficients of $\mathrm{KCl}$ in $\mathrm{KCl}+\mathrm{K} 2 \mathrm{~B} 4 \mathrm{O} 7$ $+\mathrm{H} 2 \mathrm{O}$ Ternary System at $298.15 \mathrm{~K}$ Determined by Potential Difference Measurements, Journal of Solution Chemistry, 2015, 44, 10, 2061-2072. DOI: 10.1007/s10953-015-0390-5.

[35] Manohar S., Ananthaswamy J., Atkinson G. Application of Pitzer equations for quaternary systems: sodium chloride-sodium nitrate-sodium acetate-water and potassium chloridepotassium nitrate-potassium acetate-water at 25.degree.C, J. Chem. Eng. Data, 1992, 37, 4, 459463. DOI: 10.1021/je00008a019.

[36] Giordano G.M., Longhi P., Mussini T., Rondinini S. Standard potentials in water for the potassium amalgam electrode from 283.15 to $343.15 \mathrm{~K}$ and for the potassium electrode at $298.15 \mathrm{~K}$, and thermodynamic functions for dilute potassium amalgams and for aqueous potassium chloride, Journal of Chemical Thermodynamics, 1977, 9, 10, 997-1004. DOI: 10.1016/0021-9614(77)90222-1.

[37] Manohar S., Sarada S., Ananthaswamy J. Thermodynamics of electrolyte solutions: an e.m.f. study of the activity coefficients of $\mathrm{KCl}$ in $\{\mathrm{KCl}(\mathrm{mA})+\mathrm{CaCl} 2(\mathrm{mB})\}(\mathrm{aq})$ at $298.15,308.15$, and 
318.15 K, Journal of Chemical Thermodynamics, 1989, 21, 9, 969-976. DOI: 10.1016/00219614(89)90156-0.

[38] Wu D., Qu S., Xu Z. Isopiestic activity coefficients and osmotic coefficients of sodium molybdate and sodium tungstate in aqueous solution, Journal of Chemical Thermodynamics, 1990, 22, 1, 35-39. DOI: 10.1016/0021-9614(90)90028-O.

[39] Park H., Englezos P. Osmotic coefficient data for $\mathrm{Na} 2 \mathrm{SiO} 3$ and $\mathrm{Na} 2 \mathrm{SiO} 3-\mathrm{NaOH}$ by an isopiestic method and modeling using Pitzer's model, Fluid Phase Equilibria, 1998, 153, 1, 87-104. DOI: 10.1016/S0378-3812(98)00400-2.

[40] Platford R.F. Isopiestic measurements on the system water-sodium chloride-sulfuric acid disodium salt at 25.degree : Journal of Chemical \& Engineering Data, Journal of Chemical \& Engineering Data, 1968, 13, 1, 46-48. DOI: 10.1021/je60036a015.

[41] Padova J., Saad D. Thermodynamics of mixed electrolyte solutions. VIII. An isopiestic study of the ternary system $\mathrm{KCl}-\mathrm{MgCl} 2-\mathrm{H} 2 \mathrm{O}$ at $25^{\circ} \mathrm{C}$, Journal of Solution Chemistry, 1977, 6, 2, 57-71. DOI: $10.1007 / B F 00643432$.

[42] Filippov V.K., Rumyantsev A.V., Charykov N.A. Thermodynamic Study of the Ternary Systems K+, $\mathrm{Co}(2+)-\mathrm{Cl}-\mathrm{H} 2 \mathrm{O}$ and $\mathrm{K}+, \mathrm{Ni}(2+)-\mathrm{Cl}-\mathrm{H} 2 \mathrm{O}$ at $25^{\circ} \mathrm{C}$, J. Appl. Chem. USSR, 1991, 64, 2093-2096.

[43] Rard J.A., Spedding F.K. Isopiestic determination of the activity coefficients of some aqueous rare-earth electrolyte solutions at 25.degree.C. 5. Dysprosium trinitrate, holmium trinitrate, and lutetium trinitrate, J. Chem. Eng. Data, 1981, 26, 4, 391-395. DOI: 10.1021/je00026a013.

[44] Rard J.A., Spedding F.H. Isopiestic determination of the activity coefficients of some aqueous rare-earth electrolyte solutions at 25.degree.C. 6. Europium trinitrate, yttrium nitrate, yttrium chloride, J. Chem. Eng. Data, 1982, 27, 4, 454-461. DOI: 10.1021/je00030a026.

[45] Guendouzi M.E., Dinane A. Determination of water activities, osmotic and activity coefficients in aqueous solutions using the hygrometric method, Journal of Chemical Thermodynamics, 2000, 32, 3, 297-310. DOI: 10.1006/jcht.1999.0574.

[46] Robinson R. A., Stokes R. H. Electrolyte Solutions : The measurement and interpretation of conductance, chemical potential and diffusion in solutions of simple electrolytes. Butterworths Scientific Publications, 1959.

[47] Scatchard G., Hamer W.J., Wood S.E. Isotonic Solutions. I. The Chemical Potential of Water in Aqueous Solutions of Sodium Chloride, Potassium Chloride, Sulfuric Acid, Sucrose, Urea and Glycerol at $25^{\circ}$ : Journal of the American Chemical Society, Journal of the American Chemical Society, 1938, 60, 12, 3061-3070. DOI: 10.1021/ja01279a066.

[48] Holmes H.F., Mesmer R.E. Thermodynamic Properties of Aqueous Solutions of the Alkali Metal Chlorides to $250^{\circ} \mathrm{C}$, Journal of Physical Chemistry, 1983, 87, 1242.

[49] Brown O.L. I., Delaney C.M. Vapor Pressures of Aqueous Potassium Chloride Solutions at $25^{\circ}$ by Means of a New Type of Differential Manometer, J. Phys. Chem., 1954, 58, 3, 255-258. DOI: 10.1021/j150513a018.

[50] Amado G.E., Blanco L.H. Osmotic and Activity Coefficients of Aqueous Solutions of $\mathrm{KCl}$ at Temperatures of 283.15, 288.15, 293.15 and 298.15 K. A New Isopiestic Apparatus, Fluid Phase Equilibria, 2004, 226, 261-265.

[51] Blanco L.H., Rozo A.P. Osmotic and Activity Coefficients of Trimethyloctylammonium Bromide and Decyltrimethylammonium Bromide in Aqueous Solutions as a Function of Temperature, Journal of Solution Chemistry, 2010, 39, 12, 1819-1827. DOI: 10.1007/s10953-010-9584-z. 
[52] Popović D.Ž., Miladinović J., Todorović M.D., Zrilić M.M., Rard J.A. Isopiestic determination of the osmotic and activity coefficients of the $\{\mathrm{yKCl}+(1-\mathrm{y}) \mathrm{K} 2 \mathrm{HPO} 4\}$ (aq) system at $\mathrm{T}=298.15 \mathrm{~K}$, Journal of Chemical Thermodynamics, 2011, 43, 12, 1877-1885. DOI: 10.1016/j.jct.2011.06.017.

[53] Moore J.T., Humphries W.T., Patterson C.S. Isopiestic studies of some aqueous electrolyte solutions at 80.deg, J. Chem. Eng. Data, 1972, 17, 2, 180-182. DOI: 10.1021/je60053a035.

[54] Soldano B.A., Meek M. 846. Isopiestic vapour-pressure measurements of aqueous salt solutions at elevated temperatures. Part III, J. Chem. Soc., 1963, 0, 4424-4426. DOI: 10.1039/JR9630004424.

[55] Patterson C.S., Gilpatrick L.O., Soldano B.A. 545. The osmotic behaviour of representative aqueous salt solutions at $100^{\circ}, \mathrm{J}$. Chem. Soc., 1960, 0, 2730-2734. DOI: 10.1039/JR9600002730.

[56] Held C., Reschke T., Müller R., Kunz W., Sadowski G. Measuring and modeling aqueous electrolyte/amino-acid solutions with ePC-SAFT, Journal of Chemical Thermodynamics, 2014, 68, 1-12. DOI: 10.1016/j.jct.2013.08.018.

[57] Kopecky, Dymes A. Osmometry in Vapour Phase. I. Osmotic Coefficients of Some Electrolytes at $40{ }^{\circ} \mathrm{C}$, Chem. Pap., 1972, 26, 4, 327-332.

[58] Park H., Englezos P. Osmotic coefficient data for $\mathrm{NaOH}-\mathrm{NaCl}-\mathrm{NaAl}(\mathrm{OH}) 4-\mathrm{H} 2 \mathrm{O}$ system measured by an isopiestic method and modeled using Pitzer's model at $298.15 \mathrm{~K}$, Fluid Phase Equilibria, 1999, 155, 2, 251-259. DOI: 10.1016/S0378-3812(98)00460-9.

[59] Filippov V.K., Cheremnykh L. Use of Pitzer method for calculation of solubility in systems $\mathrm{Na} / / \mathrm{Cl}$, SO4 $-\mathrm{H} 2 \mathrm{O}$ and $\mathrm{K} / / \mathrm{Cl}$, SO4 $-\mathrm{H} 2 \mathrm{O}$ at $25^{\circ} \mathrm{C} .4$ 1. Leningr. Univ, 1986.

[60] Davis T.M., Duckett L.M., Owen J.F., Patterson C.S., Saleeby R. Osmotic coefficients of aqueous lithium chloride and potassium chloride from their isopiestic ratios to sodium chloride at 45.degree.C, J. Chem. Eng. Data, 1985, 30, 4, 432-434. DOI: 10.1021/je00042a018.

[61] Kumar A. The Mixing of $\mathrm{K}+,(\mathrm{nBu} 4) \mathrm{N}+, \mathrm{Mg} 2+$, and $\mathrm{Ca} 2+$ with Guanidinium Cation in Water: Ionic Interactions from a Thermodynamic Study, J. Phys. Chem. B, 2001, 105, 40, 9828-9833. DOI: 10.1021/jp010389s.

[62] Miladinović J., Ninković R., Todorović M. Osmotic and Activity Coefficients of $\{\mathrm{yKCl}+(1-\mathrm{y}) \mathrm{MgCl}\}(\mathrm{aq})$ at T=298.15 K, Journal of Solution Chemistry, 2007, 36, 11, 1401-1419. DOI: 10.1007/s10953-007-9197-3.

[63] Soldano B.A., Patterson C.S. 175. Osmotic behaviour of aqueous salt solutions at elevated temperatures. Part II, J. Chem. Soc., 1962, 0, 937-940. DOI: 10.1039/JR9620000937.

[64] Soldano B.A., Bien P.B. Osmotic behaviour of aqueous salt solutions at elevated temperatures. Part IV, J. Chem. Soc. A, 1966, 0, 1825-1827. DOI: 10.1039/J19660001825.

[65] Guendouzi M.E., Dinane A., Mounir A. Water activities, osmotic and activity coefficients in aqueous chloride solutions at $\mathrm{T}=298.15 \mathrm{~K}$ by the hygrometric method, Journal of Chemical Thermodynamics, 2001, 33, 9, 1059-1072.

[66] Romero C.M., Blanco L.H., Gonzalez M.E., Davila M. Construction and Calibration of an Isopiestic Apparatus for Determination of Osmotic and Activity Coefficients, Rev. Colomb. Quim, 2006, 35, 2, 205-214.

[67] Wood S.A., Crerar D.A., Brantley S.L., Borcsik M. Mean molal stoichiometric activity coefficients of alkali halides and related electrolytes in hydrothermal solutions, American Journal of Science, 1984, 284, 6, 668. DOI: 10.2475/ajs.284.6.668.

[68] Patil R.K., Olive F., Coronas A. Experimental Measurement of Vapor Pressures of Electrolyte Solutions by Differential Static Method, Journal of Chemical Engineering of Japan, 1994, 27, 5 , 680-681. 
[69] Herrington T.M., Jackson R.J. Osmotic coefficients of aqueous potassium chloride solutions at 50 and $70^{\circ} \mathrm{C}$, Journal of the Chemical Society-Faraday Transactions I, 1973, 69, 0, 1635-1647. DOI: 10.1039/F19736901635.

[70] Hovey J.K., Pitzer K.S., Tanger J.C., Bischoff J.L., Rosenbauer R.J. Vapor-liquid phase equilibria of potassium chloride-water mixtures: equation-of-state representation for potassium chloridewater and sodium chloride-water, J. Phys. Chem., 1990, 94, 3, 1175-1179. DOI: 10.1021/j100366a032.

[71] Apelblat A. Vapour pressures of $\mathrm{H} 2160$ and $\mathrm{H} 2180$, and saturated aqueous solutions of $\mathrm{KCl}$ from $\mathrm{T}=298 \mathrm{~K}$ to $\mathrm{T}=318 \mathrm{~K}$ by the isoteniscopic method, Journal of Chemical Thermodynamics, 1998, 30, 10, 1191-1198. DOI: 10.1006/jcht.1998.0381.

[72] Lannung A. Measurement of the Vapor Pressure of Aqueous Solutions of the Alkali Halogenides, Z.Phys.Chem.Abt.A, 1934, 170, 134-144.

[73] Patil R., Tripathi A.D., Pathak G., Katti S.S. Thermodynamic Properties of Aqueous Electrolyte Solutions. 2. Vapor Pressure of Aqueous Solutions of $\mathrm{NaBr}, \mathrm{Nal}, \mathrm{KCl}, \mathrm{KI}, \mathrm{RbCl}, \mathrm{CsCl}, \mathrm{CsBr}, \mathrm{Csl}$, $\mathrm{MgCl} 2, \mathrm{CaCl} 2, \mathrm{CaBr} 2, \mathrm{Cal} 2, \mathrm{SrCl} 2, \mathrm{SrBr} 2, \mathrm{Srl} 2, \mathrm{BaCl} 2$, and $\mathrm{BaBr} 2$, Journal of Chemical \& Engineering Data, 1991, 36, 225-230.

[74] Tammann G. The vapor tensions of solutions, Z.Phys.Chem.Leipzig, 1888, 2, 42-47.

[75] Harrison W.R., Perman E.P. Vapour pressure and heat of dilution of aqueous solutions, Transactions of the Faraday Society, 1927, 23, 0, 1-22. DOI: 10.1039/TF9272300001.

[76] Zarembo V.I., Antonov N.A., Gilyarov V.N., Fedorov M.K. Activity Coefficients of $\mathrm{KCl}$ in the System $\mathrm{KCl}-\mathrm{H} 2 \mathrm{O}$ at Temperatures $150-350 \mathrm{C}$ and Pressures up to $1500 \mathrm{~kg} / \mathrm{cm}$, Zh.Prikl.Khim., 1976, 49, 6, 1221-1225.

[77] Sidgwick N.V., Ewbank E. The Measurement of the Vapor Pressures of Aqueous Salt Solutions by the Depression of the Freezing Point of Nitrobenzene, J. Chem. Soc., 1925, 124, 2268-2273.

[78] Smith H.A., Combs R.L., Googin J.M. Vapor Pressure Studies Involving Solutions in Light and Heavy Waters. I. The Apparatus and the Determination of Vapor Pressures at $30^{\circ}$ of Solutions of Sodium and Potassium Chlorides in Ordinary Water : The Journal of Physical Chemistry, The Journal of Physical Chemistry, 1954, 58, 11, 997-999. DOI: 10.1021/j150521a015.

[79] Filippov V.K., Yakimov M.A., Makarevskii V.M., Lukina L. Activity of Water in the $\mathrm{CdCl} 2-\mathrm{KCl}-$ $\mathrm{H} 2 \mathrm{O}, \mathrm{CdBr} 2-\mathrm{KBr}-\mathrm{H} 2 \mathrm{O}$, and $\mathrm{Cd} 22-\mathrm{KI}-\mathrm{H} 2 \mathrm{O}$ Ternary Systems at $25^{\circ} \mathrm{C}$, Russ. J. Inorg. Chem., $1971,16,11,1653-1655$.

[80] Jablczynski K. The vapor tension and the law of equilibrium of electrolytes, Rocz.Chem., 1922, 2, 467-473.

[81] Mason C.M., Gardner H.M. Isopiestic method for the determination of molecular weights, Journal of Chemical Education, 1936, 13, 4, 188. DOI: 10.1021/ed013p188.

[82] Voznesenskaya I. Vapour Pressure in the $\mathrm{NaCl}-\mathrm{NH} 4 \mathrm{Cl}-\mathrm{H} 2 \mathrm{O}$ and $\mathrm{KCl}-\mathrm{NH} 4 \mathrm{Cl}-\mathrm{H} 2 \mathrm{O}$ Systems at 50 ${ }^{\circ} \mathrm{C}$ : Deposited Doc, 1977.

[83] Krauskopf F.C. The Vapor Pressure of Water and Aqueous Solutions of Sodium Chloride, Potassium Chloride, and Sugar, Journal of Physical Chemistry, 1910, 14, 6, 489-508. DOI: 10.1021/j150114a001.

[84] Pearce J.N., Snow R.D. An Improved Dynamic Method for measuring Vapor Pressures, Journal of Physical Chemistry, 1927, 31, 2, 231-245. DOI: 10.1021/j150272a006.

[85] Lovelace B.F., Frazer J.C. W., Sease V.B. THE LOWERING OF THE VAPOR PRESSURE OF WATER AT $20^{\circ}$ PRODUCED BY DISSOLVED POTASSIUM CHLORIDE.1, J. Am. Chem. Soc., 1921, 43, 1, 102-110. DOI: $10.1021 / \mathrm{ja01434a012.}$ 
[86] Hepburn J.R. I. 69. The vapour pressure of water over aqueous solutions of the chlorides of the alkaline-earth metals. Part I. Experimental, with a critical discussion of vapour-pressure data, J. Chem. Soc., 1932, 0, 550-566. DOI: 10.1039/JR9320000550.

[87] Voinilovich G.I., Akhrap L.K., Mai L. Determination of thermodynamic properties of mineral salts solutions on the evaporation and crystallization, Zh. Prikl. Khim., 1935, 8, 4, 589-597.

[88] Kim H.T., Yoon C., Bae S.Y., Yoo K. Prediction of Activity Coefficients of Aqueous Mixed Electrolyte Solutions,, Hwahak Konghak, 1992, 30, 6, 734-748.

[89] Bykov M. The Solubility of Gases of Salts under Pressure at High Temperature, Tr. Voronezh. Gos. Univ., 1937, 9, 29-57.

[90] Higashi H., Iwai Y., Matsumoto K., Kitani Y., Okazaki F., Shimoyama Y., Arai Y. Measurement and correlation for solubilities of alkali metal chlorides in water vapor at high temperature and pressure, Fluid Phase Equilibria, 2005, 228-229, 547-551. DOI: 10.1016/j.fluid.2004.07.019.

[91] Khaibullin I.K., Borisov N.M. Experimental Investigation of the Thermal Properties of Aqueous and Vapor Solutions of Sodium and Potassium Chlorides at Phase Equilibrium, High Temperature, 1966, 4, 4, 489-494.

[92] Woldan M. Enthalpy of solution of some electrolytes in water-acetamide mixtures at $313.15 \mathrm{~K}$, Thermochimica Acta, 1986, 105, 41-49. DOI: 10.1016/0040-6031(86)85221-2.

[93] Taniewska-Osińska S., Jóźwiak M. Calorimetric investigations of solutions of $\mathrm{Nal}, \mathrm{KI}, \mathrm{NaCl}, \mathrm{KCl}$, and $\mathrm{C} 6 \mathrm{H} 5 \mathrm{NH} 2$ in [xPO"N(CH3)2' $3+(1-\mathrm{x}) \mathrm{H} 2 \mathrm{O}]$ at $298.15 \mathrm{~K}$, Journal of Chemical Thermodynamics, 1986, 18, 4, 339-349. DOI: 10.1016/0021-9614(86)90079-0.

[94] Piekarski H., Waliszewski D. Thermochemic properties of $\mathrm{NaCl}$ and $\mathrm{KCl}$ solutions in mixtures of water with N,N-dimethylacetamide at $25^{\circ}$, Thermochimica Acta, 1991, 190, 2, 299-306. DOI: 10.1016/0040-6031(91)85257-I.

[95] Lu Y., Zhen S., Lu J. The enthalpic interaction parameters of $\mathrm{NaCl}, \mathrm{KCl}$ and $\mathrm{KI}$ with acetone in water at $298.15 \mathrm{~K}$, Thermochimica Acta, 1992, 210, 15-25. DOI: 10.1016/0040-6031(92)80273-Y.

[96] Lu Y., Zhen S., Lu J. The enthalpic interaction parameters of $\mathrm{NaCl}, \mathrm{KCl}$ and $\mathrm{KI}$ with acetone in water at 303.15 and $308.15 \mathrm{~K}$, Thermochimica Acta, 1993, 221, 2, 171-181. DOI: 10.1016/00406031(93)85061-D.

[97] Woldan M. Enthalpies of transfer of alkali metal halides from water to water-acetamide mixtures, Thermochimica Acta, 1987, 111, 175-183. DOI: 10.1016/0040-6031(87)88045-0.

[98] Sanahuja A., Cesari E. Heat of solution of $\mathrm{KCl}$ in water at $303.15 \mathrm{~K}$, Thermochimica Acta, 1985, 85, 163-166. DOI: 10.1016/0040-6031(85)85555-6.

[99] Prusov A.N., Zakharov A.G., Krestov G. High-Sensitivity Calorimeter for Measuring Thermal Effects in Solutions, Izv. Vyssh. Uchebn. Zaved. Khim. Khim. Tekhnol., 1979, 22, 12, 1523-1525.

[100] Winkler M. Enthalpies of Transfer of 1-1 Electrolytes from 1-Propanol to 2-Propanol, 1982.

[101] Sanahuja A. Enthalpy of solution of $\mathrm{KCl}$ in water at 308.15 and $313.15 \mathrm{~K}$, Journal of Chemical Thermodynamics, 1985, 17, 11, 1063-1066. DOI: 10.1016/0021-9614(85)90092-8.

[102] Weintraub R., Apelblat A., Tamir A. Enthalpies of solution of rubidium halides in water, Journal of Chemical Thermodynamics, 1982, 14, 9, 887-892. DOI: 10.1016/0021-9614(82)90163$\mathrm{X}$.

[103] Korolev V.V., Egorova I.V., Krestov G. Thermochemistry of Dissolution of Potassium Chloride in Aqueous Solutions of Glycerol at Different Temperatures,, Izv. Vyssh. Uchebn. Zaved. Khim. Khim. Tekhnol., 1980, 23, 3, 306-310. 
[104] Weintraub R., Tamir A., Apelblat A. Enthalpy of solution of ammonium iodide in water, Journal of Chemical Thermodynamics, 1983, 15, 5, 403-407. DOI: 10.1016/0021-9614(83)90037$\mathrm{X}$.

[105] Spedding F.H., Miller C.F. The Heat Capacities and Heat Contents of Solutions of Cerium and Neodymium Chlorides at $25^{\circ}$, J. Am. Chem. Soc., 1952, 74, 12, 3158-3162. DOI: 10.1021/ja01132a059.

[106] Winkler M. Photocalorimetric Determination of the Binding Enthalpy of Carbonyl Complexes of the VIth Transition Element Row, 1987.

[107] Borodenko V.I., Galinker I. Heat Capacities and Heat of Dilution of Aqueous Solutions of Sodium and Potassium Chlorides at $300^{\circ} \mathrm{C}$, Izv. Vyssh. Uchebn. Zaved. Khim. Khim. Tekhnol., $1975,18,4,591-594$. 